\title{
Caribbean Faith-Based Organisations: Friend or Foe in the Fight against the Feminisation of HIV and AIDS in the Anglophone Caribbean
}

\author{
Shivaughn Hem-Lee-Forsyth, PhD, MPH and Renee Thomas*, MPH \\ Department of Public Health and Preventive Medicine, St. George's University, Grenada \\ ${ }^{\star}$ Corresponding author: Renee Thomas, Department of Public Health and Preventive Medicine, St. George’s University, Grenada
}

Received: September 23, 2021; Accepted: September 29, 2021; Published: October 21, 2021

\begin{abstract}
The feminisation of HIV and AIDS has become a worldwide phenomenon, and the Caribbean region has not been fortunate enough to be excluded. Caribbean females had 3-4 times higher infection rates than males up to a decade ago. Studies that focus on the contributing psychosocial factors to HIV risk in the Caribbean are limited. This narrative review showcases pivotal work which addresses the reciprocally connected responsibilities of patriarchy and religious practices and how they feed into the desolate reality of Anglophone Caribbean women. The relationship between these cultural issues in the Caribbean, using an anthropological lens, sets a platform for an investigation into HIV and AIDS. This paper seeks to encourage further research centred on the religious elements, which influence heterosexual relationships, and how these relationships are predisposed to potential HIV and AIDS risk. The ultimate goal of this study is to provide English- speaking Caribbean faith-based organisations, public health officials and policymakers a public stage to consider further policy implications for the staggering and disproportionate rates of HIV and AIDS between women and men.
\end{abstract}

Keywords: Anglophone Caribbean women, Faith-based organisations, Patriarchy, Feminisation of HIV and AIDS, Heterosexual relationships

\section{Introduction}

HIV and AIDS is an ongoing public health concern in the Caribbean community, with the second-highest HIV prevalence after Sub-Saharan Africa (Avert, 2020). Globally, there are almost equal infection rates among women and men. In Caribbean nationstates, like other countries, however, more women, as opposed to men, are particularly vulnerable to this epidemic: women account for approximately 53\% of all reported HIV cases (UNAIDS, 2020). Currently, women, including transgender women, contract HIV disproportionally compared to the rates of men, and the gap continues to increase among certain groups (Avert, 2020). For example, in Trinidad and Tobago, HIV and AIDS rates are five times higher for girls than boys ages 15-19 (Pan American Health Organization (2011). These trends have initiated united cooperation between local and regional health and gender agencies to reverse the spread of this feminised disease within Caribbean territories.

\section{Methodology}

A comprehensive narrative review was conducted to identify research articles that explored the Feminization of the HIV and AIDS epidemic and the contributing role of Faith-Based Organisations in dealing with this infectious disease challenge in the Caribbean. The literature search also included current rates and trends of disease transmission according to gender within the Caribbean region. For this study, women were defined as cisgender and did not include women in the transgender community. This review included the analysis of peer- reviewed articles and official reports from international and regional public health agencies. Library databases were the primary tool used for the literature search. The World Health Organization, The Joint United Nations Programme on HIV/AIDS, The Pan American Health Organization and The United Nations Women Entity for Gender Equality and the Empowerment of Women websites were also used to access fact sheets and other pertinent data on HIV and AIDS.

Collection of the literature was done using the following search terms: "Faith-Based Organisations and HIV and AIDS," "HIV and AIDS in the Caribbean," "Women and HIV and AIDS," and "Religion and HIV and AIDS." All articles were evaluated for their relevance and applicability to the themes that were to be explored. A total of twentythree (23) data sources were used for this literature review. Most of the articles selected were published within the last twenty years. An exception was made to include an article outside the specified period since the covered information is still relevant today. The findings were categorised into four different themes, which underscored the importance of addressing the Feminization of HIV and AIDS in the Caribbean and the role of religious organisations in ameliorating the situation.

\section{Women and HIV Risk}

Despite the continued recognition of women's alarming HIV and AIDS case numbers, with their concomitant high-risk sexual practices, the perceived HIV risk can be best described as low to moderate. This low perception of women's HIV risk can be attributed to multiple 
determinants, including generational knowledge, traditional practices, and misconceptions regarding safe sex behaviours (Charlery, 2005). Primarily, these cultural beliefs are responsible for driving unsafe sexual behaviours, which threaten many women's physical and mental health. Because of this disconcerting truth, attending to HIV and AIDS within the Caribbean is vital by targeting female groups with the worst health outcomes. This public health matter will require a multisectoral approach to reduce the incidence of HIV among Caribbean women. The religious community plays a prominent role in Caribbean society and can be a chief ally in pursuing greater HIV awareness and well-being among the female fellowship.

Faith-based values and beliefs are at the heart of Caribbean culture, and they play an integral role in the ways people relate one to the other. Religious dogma also influences the attitudes and behaviours which govern these human interactions. Sometimes, these religious doctrines are viewed as a purposive extension and perpetuation of patriarchy: a means of advocating and maintaining social control. Soares (2005) elucidates, "This ideology of male dominance, which underlies society's oppression of and discrimination against women, is often encouraged by social and cultural institutions such as the church [1]. "Socio-cultural perspectives as they relate to religious cosmology are therefore linked to gender inequity.

As part of the societal norms, gender disparities have become a driving force, integral to the feminisation of HIV and AIDS. To mitigate this harmful outcome, "Acknowledgement must be made of Caribbean gender politics and its obliteration of true female agency. The negative repercussions of cultural indoctrination on all women within a patriarchal system must also be given prominence" [2]. All persons are entitled to what Soares (2005) describes as "gender justice" [1]. [This is where] "the same rights, freedoms, opportunities, recognition, and respect for all women and men regardless of their position in society, race and colour identity, religious persuasion, ethnic origin, and sexual orientation" [are given]. Opportunities should be awarded to everyone in a utopian world, especially those traditionally dispossessed and disadvantaged by their life's circumstances. Does religion, therefore, provide this space for espousing "gender justice," or does it epitomise and propagate gender injustice?

\section{The Role of Religion}

Religions practised in the Caribbean such as Christianity, Hinduism, Islam, and Rastafarianism all have clearly defined positions on the gender issues raised in this discourse. Collectively, these religions add to the complexity of the problem involving HIV and AIDS and women. For this discussion, allusion will be principally made to Christianity as it is the most pervasive religion. The Holy Bible, in Isaiah 61:1, preaches that people should live their lives following the example of Jesus Christ, whose coming was "to proclaim liberty to the captives and to heal the broken-hearted." These "captives" and "the broken-hearted" refer to the oppressed in the society, such as women, gay men, sex workers and the poor, all of whom are at high risk of HIV. Therefore, it seems logical that Christians should devote themselves to eradicating injustices meted out to these groups. Isaiah presents God's message, "I love justice and hate oppression," while another prophet warns that "injustice is unrighteous and sinful" [1]. On this premise, religious leaders should cry out against abhorrent acts of inequalities and discrimination against disenfranchised communities, and in this case, vulnerable and victimised women. The revered God is the epitome of love and would therefore want justice for all. The conflict lies in reconciling what the Holy Bible says and what the church preaches.

The machismo culture (masculinity) and marianismo culture (femininity) in the Caribbean aligns with Christian values and influences women's exposure and vulnerability to HIV and AIDS. Marianismo (derived from the Virgin Mary) portrays the ideal woman as modest, pure, dependent, weak, acquiescent, vulnerable, and abstinent until marriage. In this sense, "femininity" implies that a woman must be innocent and self-sacrificing, placing the needs and desires of her husband before herself [3]. Gupta (2002) and PAHO (2002), as cited in Hem-Lee-Forsyth (2019), explained that marianismo requires "good" females to be Virgin Mary like, and to possess less information on matters related to sex, as more knowledge might be indicative of promiscuous activities or extramarital relations [3-5]. Christianity, which can act as a conduit of machismo, teaches that the man is the head of the home and the wife must submit to him. According to 1 Corinthians 11:3: "Christ is supreme over every man; the husband is supreme over his wife".

The everyday living of "good" Christians often reflects this philosophy of male dominion over the subservient woman as part of the divine design. In cases of infidelity, domestic violence, and any abuse in the marriage, where men are the primary perpetrators, these acts are often described as "their [women's] cross to bear;" spouses are encouraged to forgive and work through their differences, and mend the relationships [6]. Male privilege is yet again demonstrated as reigning supreme in the private and intimate lives of women. Gleeson, 2017, p. 12, questions whether "an all-male hierarchy [in the church] [even] capable of responding effectively to gendered violence?" if called on to provides an intervention [6]. Many couples, therefore, end up staying together "for richer or poorer, in sickness and in health, to love and to cherish, till death do [they] part," although their relationships can potentially lead to the detriment of the women's welfare. This case demonstrates that these types of social constructs, which put women in harm's way, are seldom contested by religious organisations. It is heartening to see that Christians are becoming more progressive on the current surge of domestic abuse incidents and are encouraged to leave due to the lower stigma attached to divorce [6].

Despite the Caribbean's religiosity, particularly among Christians who are proponents of monogamy, the Caribbean seems more tolerant of male promiscuity than female promiscuity. With that said, monogamy is the most apparent solution for HIV and AIDS prevention [7]. Some worshippers hold the religious belief that chastity until marriage guarantees disease prevention [8]. For Christian Catholics, engaging in sexual intercourse within the sanctity of marriage prohibits all contraceptive methods. Irrevocably, for those who heed this instruction, their HIV risk is increased, particularly if spouses are engaging in extramarital sexual relationships.

Similarly, male supremacy in the Caribbean Rastafarianism appears to be the order of the day; males are the physical and spiritual 
leaders of the household. Teachings in the Rastafarianism religion are derived from Christianity; many biblical references to wives submitting to their husbands are similar to Rastafarianism [9]. Some Muslims are strong supporters of the practice of polygamy. Only the first wife is recognised in Caribbean civil law, and the others are common-law wives. The lack of urgent attention paid to this polygamous practice by civil society and other interest groups contributes to the spread of HIV as there is no surety as to whether the husband and his wives will remain faithful. In the Caribbean, collectively, the tenets of these religions tend to preserve and even bolster gender bias; inadvertently, this actuality affects women's health to a higher degree than their male counterparts.

\section{Religion and Marginalised Groups}

Religious groups have consensus on and have publicly lauded the prohibition of prostitution and homosexuality. Most English-speaking Caribbean countries have criminalised both; nonetheless, these "illegal acts" are still widespread with few or no convictions at all. However, it is common knowledge that several churchgoers overtly condemn and demonise any semblance of sex work or LGBTQIA+ orientation. In a one of its kind study done in Grenada on the views of the Grenadian faith-based community on HIV and AIDS, Gomez and Alexis-Thomas found that church members do not alienate these groups; instead, they offer advice and counselling in the hope that they change their "illegal," "wrong" and "sinful" lifestyle [10].

In so far as HIV-risk taking behaviour is concerned, this is frowned upon by most religious communities. Inevitably, these organisations are faced with a predicament: on the one hand, there is a celebration of abstinence and fidelity, but on the other, there is a lack of compliance by devotees, thereby contributing to increased risk-taking practices in the general public. Although these religious sects have traditionally assumed crucial roles vis à vis education and social justice, discussions in this modern era on gender, sexual health and safe sex continue to be taboo- often deemed irreconcilable with most Christian beliefs. Nonetheless, the struggle for advocacy around these serious issues should be pursued. In a study, Cotton, Puchalski, Sherman et al., emphasised that religion could be a great source of solace for individuals living with HIV [11]. Within the study, most individuals belonged to a religious community; they credited their faith-based organisation to boost their self-esteem and optimism towards their future lives [11]. Although this study was conducted in the United States, lessons can be easily extrapolated in the Caribbean context, of which there is a dire need for redress.

It is undeniable that followers are impressed by religious influences on societal values and norms in everyday living. In Matthew 25:35-36, the Holy Bible stresses the importance of helping those individuals in need. To fulfil that obligation, religious organisations and their affiliates participate in service activities centred around serving underprivileged and dispossessed community members. However, as expounded previously, this practice does not transcend affairs related to gender and sexual health. In Gomez \& Alexis-Thomas, the unfortunate actuality that came to the fore in that study is the Herculean task of obtaining buy-in from religious leaders to embark on health campaigns targeting sexual health matters [10].
The unswerving heterosexual thrust of marianismo and Christianity can be linked to the feminisation of HIV and AIDS in the Caribbean. At such an inopportune moment in history, the insistence on heteronormality, and the blatant denial and rejection of same-sex sexual orientation, provide a thriving environment for stigmatisation of lesbian and bisexual women. According to PAHO, this makes it difficult for women who have sex with women to access sexual health information and services, including appropriate barrier methods used for safer sex [3]. This resolute and myopic position on human sexuality within religion-based organisations presents an obvious quandary in striking a balance between the need to assist the public through sexual health education and doing it in such a way sans compromise of integrity regarding religious beliefs.

\section{Perspectives from the Religious Communities}

The religious community's dilemma is being the champion for social justice and being the defenders of their faith. The Holy Bible says, "Do not be unequally yoked with unbelievers. For what partnership has righteousness with lawlessness; sin is lawlessness" (In 2 Corinthians 6:14).

For members of the Christian public, this passage suggests avoiding any association with unrighteous practices. While Christianity typically has a mission of service, education, and social justice, its followers are also required to uphold their faith without compromising the teachings of the Holy Bible.

For conservative Christians, in particular, participating in sexual health education presents a potential threat to their beliefs, teachings, and perspectives. According to a study conducted in Jamaica, there are faith-based initiatives to tackle the HIV and AIDS crisis in the country; however, these initiatives are not well-documented. Nevertheless, Christian establishments give support dedicated to sexual health education through their HIV and AIDS ministries. These services come in the form of psychosocial and family life counselling, health fairs, and seminars/workshops. While stigma and discrimination towards risky sexual behaviours are still prevalent in the Caribbean, these religious bodies respond to the loud cry to the cause by making provisions for disenfranchised groups within their communities [12].

In different country contexts, there is documented evidence that reinforces the fact that the church does sterling work in health promotion services. For example, in the United States, the Black church plays an essential role in offering health education programming to its membership. Austin and Harris examined the role of the Black congregation in transmitting health information, which included HIV and AIDS materials [13]. The study highlighted the benefits of bringing awareness to the community, including increased discussion among family members about trepidations regarding their health; and ensuring that communities are empowered to take personal responsibility for their holistic health care.

Historically, the Black church has been an indispensable source of general assistance to the African American community; in this regard, there is a greater likelihood that educational resources shared by church volunteer personnel will be more welcomed and trusted than similar resources presented by the external community healthcare workers. In 
addition, the church provides a safe and suitable site: multiple media can be employed to inform the flock about the different sexual health risks and the importance of screening for HIV and AIDS, and selfhelp groups can provide morale-boosting conversations around daily sexual health activities. Further, church settings and other community type centres are also less stigmatising than clinics, and the setting up of health centres can serve as testing or treatment centres [14]. Similarly, in the Caribbean, houses of religion can become the backbone of health and social support for members, providing well-needed resources on HIV and AIDS in their respective communities.

Acknowledging that faith-based organisations may be reluctant to engage in sexual health education, there may be other avenues to reduce the spread of HIV and AIDS among women. Several of the women in the Caribbean considered to be at high risk of HIV are sex workers. According to Sharpe \& Pinto, some of these women are unemployed and are responsible for caring for their family members [15]. Religious organisations can indirectly assist these women through self-empowerment programs that educate and equip them to gain employment and subsequent financial security. These organisations can also implement social safety net programs to provide food security, housing, and financial aid for children and the elderly within vulnerable households. There are creative ways that faithbased organisations can alleviate the burden of the ongoing epidemic; this can be carried out in a manner that aligns with their beliefs and practices. Moreover, HIV and AIDS activists and other interest groups should not rule out the possibility of garnering attention from the religious community. On the contrary, these groups should foster meaningful relationships; engage in meaningful conversations with the religious communities; create healthy and happy societies.

In numerous capacities, Caribbean faith-based organisations have taken the mantle to assist communities with natural disasters, pandemics such as COVID-19, and other public health hurdles such as chronic and lifestyle diseases. Consequently, there are limited reasons to believe that the HIV and AIDS epidemic is any different: religious organisations do have a role in confronting the existence of HIV and AIDS. Organisations are constantly changing and evolving to meet the demands of society. Religious communities should boost efforts to help the most susceptible female populations in society. Undoubtedly, this will be a somewhat novel and challenging venture for most religious groups; however, with the proper guidance to execute community programs from public health institutions and non-profit organisations, this undertaking can indeed exist. With this combined stakeholder engagement, there will be positive outcomes when grabbling with the feminisation of HIV and AIDS.

\section{Conclusion}

Internationally, as The Joint United Nations Programme on HIV/ AIDS [UNAIDS] and critical patrons strive to end the HIV and AIDS epidemic by 2030 aggressively, it is also of utmost importance to consider the feminisation of HIV and AIDS. In the Caribbean community, religious groups are significant partners and influencers; in this regard, their power of influence on the cultural practices of their people is second to none. Notably, Caribbean societies are matriarchal- women often lead households; furthermore, females play pivotal roles within the religious community. With prominent female leadership engagement within religious institutions, strategically, women are positioned to challenge gender norms and advocate for gender equality; this affirmative action will lead to an emphatic win: a reduction in the feminisation of HIV and AIDS.

According to the Kaiser Family Foundation Global Health Policy, approximately $50 \%$ of people living with HIV in the Caribbean have suppressed viral loads, below the global average of 59\% [16-22]. This statistic indicates that Caribbean islands lag behind the rest of the world in guaranteeing equitable access to medication for blood viral load reduction in HIV patients. At this juncture, further scrutiny into discrepancies of viral load within the Caribbean compared to the rest of the world and viral load differences among genders is warranted.

This article mainly draws on resources from countries outside of the Caribbean region for comparisons and recommendations. There are limited regional analyses that focus on religion's role in the fight against the feminisation of HIV and AIDS. Findings and recommendations on men who have sex with men and transgender women, both associated with the feminisation of HIV and AIDS in the Caribbean, have not been included in this manuscript. Considering both identities in the discussion on HIV and AIDS within religious organisations for future studies must be considered. Indisputably, apart from religious communities, there are many other communities providing opportunities for scholars to explore other pertinent and interconnected areas of HIV research to concentrate on the ongoing HIV epidemic. Anthropological factors, and their influence on HIV and AIDS, need to be a focal point of the exploration if there is any hope of reversing the feminisation of HIV and AIDS in Caribbean nations.

\section{References}

1. Soares J (2005) Gender justice and the Christian mission. Journal of Religious Thought 57: $67-82$.

2. Hem-Lee-Forsyth S (2019) Carnival bacchanal culture and the silent HIV risk among female Caribbean professionals. International Journal of Public Health 11: 413-423.

3. Pan American Health Organization. (2011). The UNGASS, Gender and Women's Vulnerability to HIV/AIDS in Latin America and the Caribbean. PAHO.

4. Gupta RG (2002) Vulnerability and resilience: Gender and HIV/AIDS in Latin America and the Caribbean.

5. Hem-Lee-Forsyth S, Hunter C, McNab J, Ku C (2019) Culture and its impact on the feminisation of HIV and AIDS risk among Caribbean women. International Journal of Gender and Women's Studies 7: 17-28.

6. Gleeson H (2017) 'Their cross to bear': The Catholic women told to forgive domestic violence. ABC News Australia.

7. Mount Holyoke, Roberts D, Reddock R, Douglas D, Reid S (2009) Sex, power and taboo: Gender and HIV in the Caribbean and beyond. Kingston: Ian Randle Publishers.

8. Voelker R (2005) Women shoulder growing HIV/AIDS burden. JAMA 293: 281-282. [Crossref]

9. Lake O (1994) The Many Voices of Rastafarian Women: Sexual Subordination in the midst of Liberation. New West Indian Guide 68: 235-257.

10. Gomez A, Alexis-Thomas C (2010) HIV/AIDS: perceptions of the Grenadian faithbased community. West Indian Medical Journal 59: 356-361. [Crossref]

11. Cotton S, Puchalski CM, Sherman SN, et al. (2006) Spirituality and religion in patients with HIV/AIDS. Journal of general internal medicine 21: S5-13. [Crossref] 
Renee Thomas (2021) Caribbean Faith-Based Organisations: Friend or Foe in the Fight against the Feminisation of HIV and AIDS in the Anglophone Caribbean

12. Muturi N (2008) Faith-Based Initiatives in Response to HIV/AIDS in Jamaica. IJOC 108-131.

13. Austin S, Harris G (2011) Addressing Health Disparities: The Role of an African American Health Ministry Committee. Social Work in Public Health 26: 123-135. [Crossref]

14. Pillay Y (2011) The Role of the Black Church, the Barbershop/Beauty Salon, and Digital Communication to Support African American Persons Living With HIV/ AIDS. Journal of Creativity in Mental Health.

15. Sharpe J, Pinto S (2006) The Sweetest Taboo: Studies of Caribbean Sexualities; A review essay. Journal of Women in Culture and Society 32: 247-274.

16. King James Bible (2021) King James Bible Online. The Global HIV/AIDS Epidemic. Kaiser Family Foundation.

17. Francis C, Lewis-Agard N (2020) Faith Based Efforts in the Caribbean to Combat Discrimination Based on Sexual Orientation and Gender Identity. Arcus Foundation.
18. Lazarus L (2012) This is a Christian Nation: Gender and Sexuality in Processes of 9 Constitutional and Legal Reform in Jamaica. Social and Economic Studies 61 (3) Special issue on women's health and rights in select Caribbean countries (September 2012).

19. Pan American Health Organisation (2002) Gender and HIV/AIDS in Latin America and the Caribbean. [Fact Sheet].

20. Reed CS (2014) Sexual \& Reproductive Health of Dutch Afro-Caribbean Women: An Analysis of Culture, Reproductive Statistics and Black Female Sexuality.

21. Susser I, Stein Z (2000) Public health matters: Culture, sexuality, and women's agency in the prevention of HIV/AIDS in Southern Africa. American Journal of Public Health 90: $1042-1048$.

22. The United Nations Entity for Gender Equality and the Empowerment of Women. (2015). Facts and figures: HIV and AIDS. US Agency for International Development.

\section{Citation:}

Hem-Lee-Forsyth S, Thomas R (2021) Caribbean Faith-Based Organisations: Friend or Foe in the Fight against the Feminisation of HIV and AIDS in the Anglophone Caribbean. ARCH Women Health Care Volume 4(4): 1-5. 